\title{
UNDULATED : A NEW GENETIC FACTOR IN MUS MUSCULUS AFFECTING THE SPINE AND TAIL
}

\author{
BY MARGARET E. WRIGHT \\ Department of Genetics, Cambridge
}

\section{ORIGIN}

Received 2.i.47

IN December I943 some mice were obtained from a fancier in Cambridge, and an assistant of this Department, Miss J. Morton, noticed that they had kinked tails. This anomaly has been investigated by Mrs V. P. Leonard and myself.

\section{INHERITANCE}

Breeding tests have shown the deformity to be due to a single recessive gene, to which the name "undulated" has been given. The gene promises to be useful genetically as there are no normal overlaps and no apparent reduction of viability in the nest (see table I and the graph). Crosses were made into many unrelated stocks, and in none of them was there a significant deficiency of un un mice.

TABLE I

\begin{tabular}{|c|c|c|c|c|c|}
\hline Type of mating & $\begin{array}{l}\text { No. of } \\
\text { matings }\end{array}$ & $\begin{array}{c}\text { No. of } \\
\text { normals }\end{array}$ & $\begin{array}{l}\text { No. of } \\
\text { affected }\end{array}$ & Totals & $x^{2}$ \\
\hline $\begin{array}{l}\text { 1. un un } \times \text { un un } \\
\text { 2. Outcrosses } \\
\text { 3. Backcrosses } \\
\text { 4. Intercrosses. }\end{array}$ & $\begin{array}{r}4 \\
16 \\
5 \\
12\end{array}$ & $\begin{array}{r}0 \\
27^{8} \\
4^{8} \\
239\end{array}$ & $\begin{array}{r}32 \\
0 \\
46 \\
76\end{array}$ & $\begin{array}{r}32 \\
278 \\
94 \\
315\end{array}$ & $\begin{array}{c}\ldots \\
\cdots \\
0 \cdot 0018 \\
0 \cdot 0022\end{array}$ \\
\hline
\end{tabular}

\section{VIABILITY}

The death-rate of adult " undulated" does was seen to be slightly lower than that of "undulated" bucks-from an examination of the mortality of some 85 does and $8 \mathrm{I}$ bucks. The mortality of the affected animals (totalling I66) is greater than that of the unaffected sibs from matings involving "undulated" (totalling 466) (see the graph of the $\log _{e}$ Mortality Curve).

\section{FERTILITY}

The fertility of both sexes is impaired, but here the females are more affected than the males. Three does never bred out of thirteen mated, while two bucks never bred out of twenty-one mated. These 
small figures show the comparative infertility of 23.02 per cent. of does and 9.52 per cent. of bucks. This excludes two matings which did not breed, in which both mice were un un.

\section{EXTERNAL APPEARANCE}

un un mice have kinked tails at birth, the kinks occurring at fairly regular intervals and being soft to touch. One cannot feel the deformity by running the tail between the fingers, but the kinks

Loge Mortality Curve

Normal mice - - -

Undulated mice

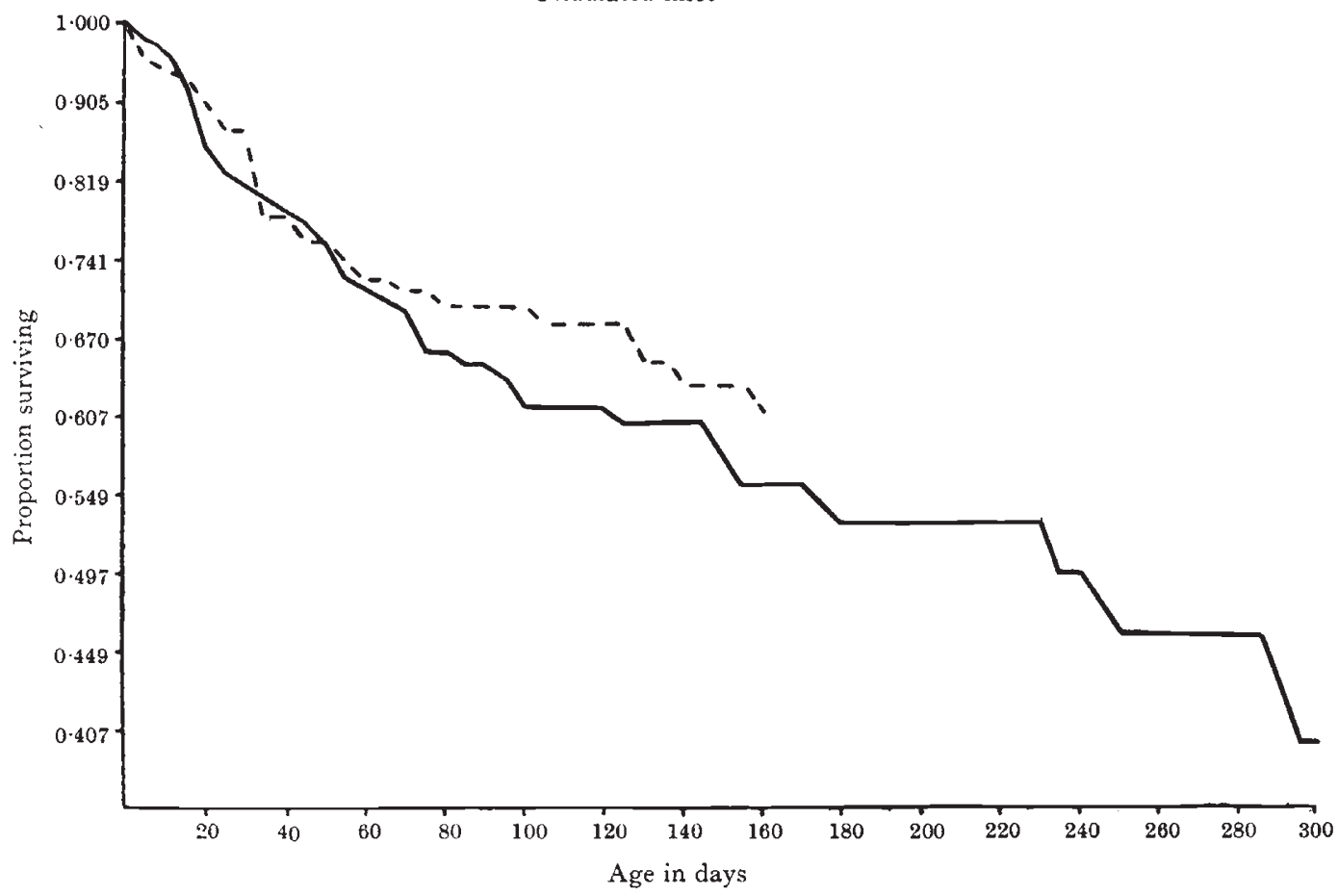

return as soon as the tail is released. This fact enables distinction to be made at birth between un un mice and any showing accidental kinkiness. However, classification cannot always be made with certainty for several days because the gene varies its expression from slight to extreme undulation, as can be seen from the photographs of live mice (plate); and the more slightly manifesting mice may have to await confirmation of classification until as much as eighteen days. No data are available to show whether the degree of expression is due to genetic or environmental causes. At about fourteen days most un un mice show characteristic Spondylitis deformans, the spine being humped in the thoracic and depressed in the lumbar region. This hunchback seems correlated with greater undulation of the tail, 
and is probably a more extreme manifestation of the gene. In later age the kinks in the tail become hard to the touch, like Danforth's short tail (Sd) and Fused (Fu) and old un un mice show very deformed, and sometimes very twisted, backs.

\section{SKELETAL DEFORMITY}

That the deformity is not merely muscular is shown by the fact that un un mice do not lose their kinks when dead or under an anæsthetic. In the young mice the vertebræ are deformed, as can be seen from transparencies (see the plate). The general appearance of the vertebræ of the thoracic, lumbar, sacral and coccygeal regions is that of irregular growth of the processes and bodies. There is no uniformity in this; for instance, the right side of the neural arch and articular processes is longer than the left in some vertebræ, and the reverse is true for others. In consequence the twist is from side to side. Fig. I shows the outlined part of the

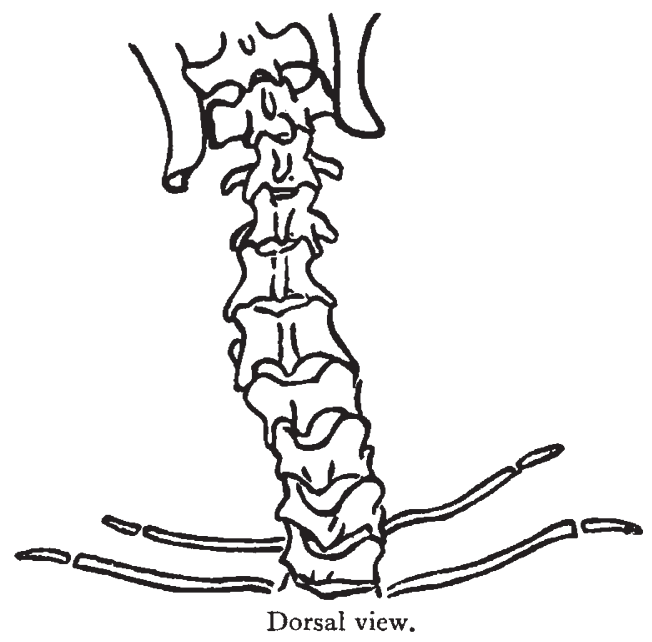

Fig. I,-Extreme un un.

extreme "undulated" shown in No. I of the plate. There is evidence to suggest irregular growth of the edges of the epiphyseal plates of the bodies. This is most marked in the coccygeal region; the right or left edge of this plate appears thicker than the other, which gives the appearance of unequal length of the two sides of the body and would account for the twist. It is possible the deformity is due entirely to irregular development of the ossification centres; on the other hand, abnormal development of the axial musculature, producing tensions on the developing bones may be the prime cause, with ossification changes consequent upon this. The appearance of the vertebral column and ribs in the $S d u n /+u n$ mouse shown in No. VI of the plate is suggestive of this. Nos. III, IV and V show a Fu un/+un, a normal and a $S d$ not "undulated" for comparison. Figs. 2-4 
represent the outlined parts of Nos. II, V and III, and show the difference between the deformity due to un un and that due to $F u+$ and $S d+$; the deformity due to the former is fairly continuous and consists of irregular elongations of the vertebræ, with slight degeneration at the end of the tail (but no vertebræ have been missing in the few transparencies made), while both the latter deformities are abrupt and consist of fusions, degenerations, absences and misplacements of the vertebræ.

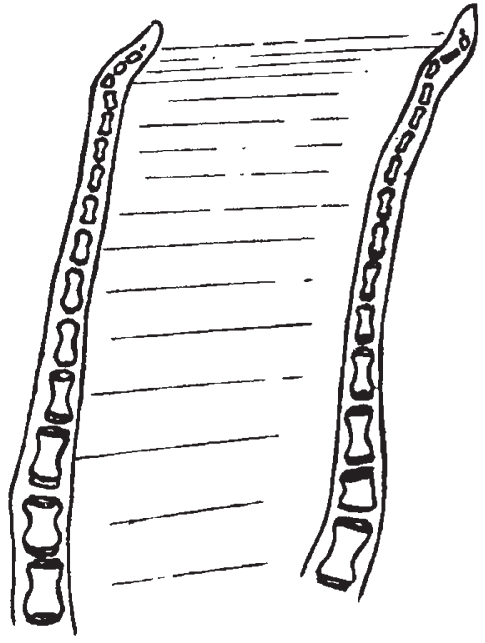

Dorsal view.
Lateral view.

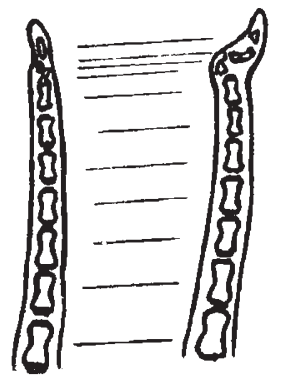

Dorsal view. Lateral view. Fig. 3. $-S d+$ not undulated.



Dorsal view.

FIG. 2.-Slight un un.

\section{IDENTITY TESTS}

"Undulated" has been tested with three other tail deformities in our stocks. Being a recessive it cannot be the same gene as $F u$ or $S d$, and backcrosses in coupling with $F u$ and $S d$ show that it is not an allelomorph of these genes since normals were thrown (see table 2).

TABLE 2

\begin{tabular}{|c|c|c|c|c|c|c|c|c|c|c|}
\hline \multirow{2}{*}{$\begin{array}{c}\text { Gene } \\
\text { tested } \\
\\
\\
\\
c c\end{array}$} & \multirow{2}{*}{$\begin{array}{l}\begin{array}{l}\text { Kind of } \\
\text { mating }\end{array} \\
\\
\text { Repulsion } \\
\text { intercross }\end{array}$} & \multirow{2}{*}{$\begin{array}{c}\text { No: of } \\
\text { matings } \\
3\end{array}$} & \multicolumn{4}{|c|}{ Phenotypes } & \multirow{2}{*}{$\begin{array}{c}\text { Totals } \\
\\
\end{array}$} & \multirow{2}{*}{$\begin{array}{l}\begin{array}{l}\text { Total } \\
\text { score }\end{array} \\
-6 \cdot 222\end{array}$} & \multirow{2}{*}{$\begin{array}{c}\text { Amount of } \\
\text { information } \\
245 \cdot 333\end{array}$} & \multirow{2}{*}{$\begin{array}{c}\begin{array}{c}\text { Cross- } \\
\text { over } \\
\text { values }\end{array} \\
\begin{array}{c}\text { Per cent. } \\
52 \cdot 5\end{array}\end{array}$} \\
\hline & & & $\begin{array}{c}c+ \\
26\end{array}$ & $\begin{array}{c}+u n \\
29\end{array}$ & $\begin{array}{c}++ \\
71\end{array}$ & $\begin{array}{c}c, u n \\
12\end{array}$ & & & & \\
\hline$F u$ & $\begin{array}{l}\text { Coupling } \\
\text { backcross }\end{array}$ & I & $\begin{array}{c}F u+ \\
3\end{array}$ & $\begin{array}{c}+u n \\
\text { I3 }\end{array}$ & ${ }_{12}^{++}$ & $\begin{array}{c}F u \text { un } \\
4\end{array}$ & 32 & 0.000 & $128 \cdot 000$ & $50 \cdot 0$ \\
\hline$S d$ & $\begin{array}{l}\begin{array}{c}\text { Coupling, } \\
\text { single } \\
\text { backcross }\end{array} \\
\frac{S d+}{+u n} \times \frac{++}{+u n}\end{array}$ & 2 & $\begin{array}{c}S d+ \\
\text { I } 4\end{array}$ & $\begin{array}{c}+u n \\
9\end{array}$ & $\begin{array}{c}+t \\
29\end{array}$ & $\underset{6}{S d, u n}$ & $5^{8}$ & $3 \cdot 999$ & $77 \cdot 333$ & $44^{\cdot 8}$ \\
\hline
\end{tabular}




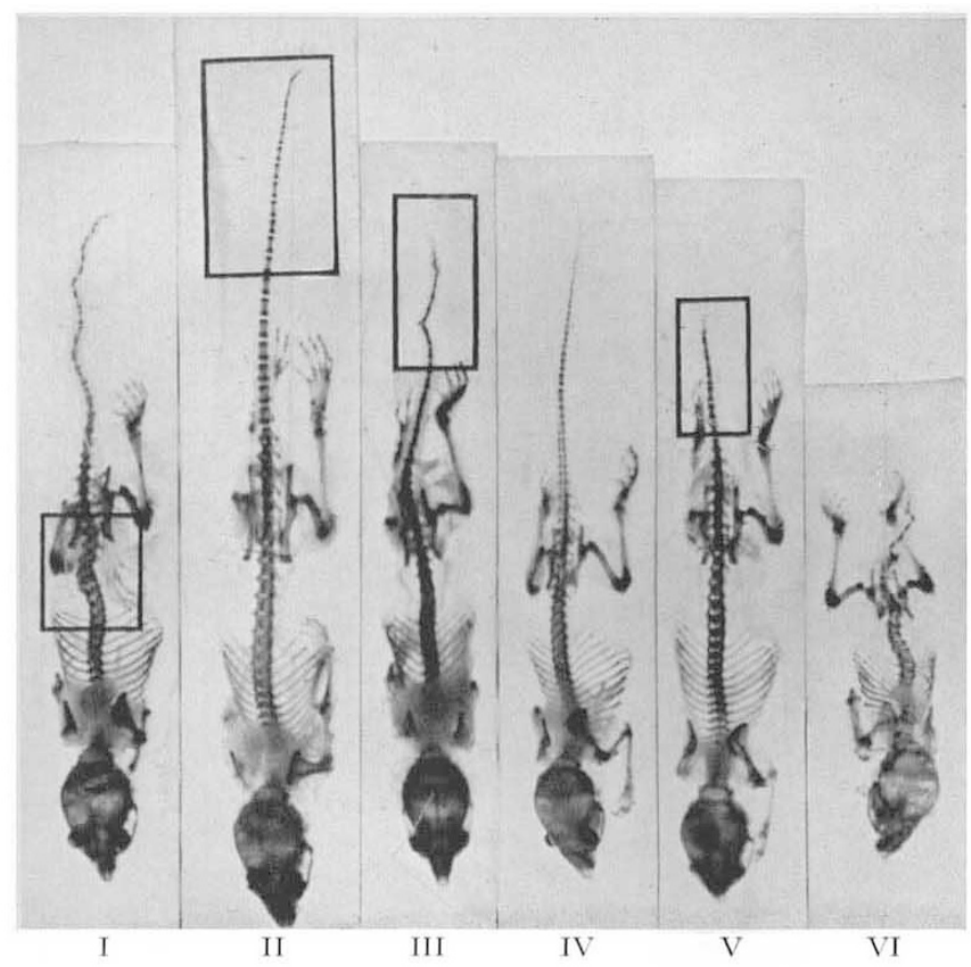

$\begin{array}{cl}\text { Extreme } & \text { Slight } \\ \text { un un } & \text { un un }\end{array} \quad$ Normal $\quad \begin{aligned} & S d+\text { not } \\ & \text { "undulated }\end{aligned}$

Note.-These transparencies are of mice 20-30 days old

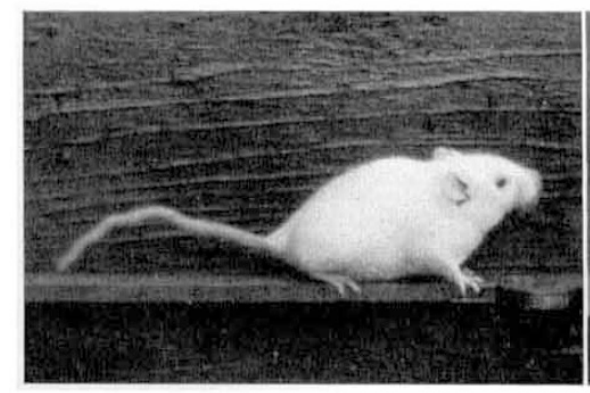

A slight " undulated "

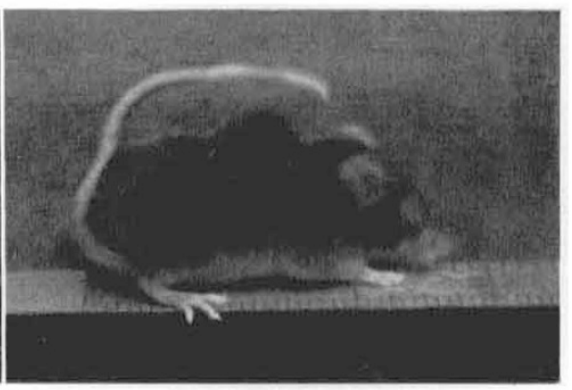

An extreme " undulated " 
Its appearance and effects are also quite different from flex-tail, as it has full manifestation and the young do not show any anæmia. When crossed to flex an un un doe threw all, out of four, non-anæmic and with normal tails. We have been unable to find any description of a tail deformity in the literature that is at all similar to "undulated."

\section{LINKAGE TESTS}

In the course of breeding, data have accumulated on linkage with $F u, S d, c c$ (albinism) and $A$ (agouti). As can be seen from the results summarised in table 2, there is no indication of linkage with the first three factors. Mr T. C. Carter, then working in this department, has since informed me of close linkage with the agouti locus. Systematic linkage tests are being carried out with the other genes of this linkage group in Professor Fisher's stocks.

The method of assessing linkage evidence is described by Fisher (1946).

I am very grateful to Professor R. A. Fisher for his guidance and advice and for supplying the analysis of the death-rate of " undulated "; to Mrs V. P. Leonard for permission to use her data; and also to Mr C. W. Ottaway, F.R.C.V.S., for his report on the anatomical effects of the gene.

\section{REFERENCE}

FISHER, R. A. . . . . . 1946. Amer. Nat., 80, 794, 568-578. 